\title{
Using social networks as a catalyst for change in global higher education marketing and recruiting
}

\author{
University of Worcester, \\ Henwick Grove, Worcester, WR26AJ, UK \\ E-mail: j.kuzma@worc.ac.uk \\ E-mail:w.wright@worc.ac.uk \\ *Corresponding author
}

Joanne M. Kuzma* and Warren Wright

\begin{abstract}
Higher education institutes (HEIs) throughout the world are recognising the potential of using social networking as an outreach method for their marketing and recruiting campaigns and can serve as a catalyst for strategic change within the education sector. This study researched 90 universities in Asia, Africa and Europe to their use of social networking for educational recruiting and marketing. Results showed that HEIs in certain geographic areas do use it, but results are inconsistent among the globe. The innovative functionality provided by social networking has challenged HEI officials who may be inexperienced at utilising the full potential of these sites to better serve the school and its stakeholders. However, it is important that HEIs integrate the use of social media into their marketing programmes in order to better reach their intended audiences and provide for a more successful education experience for students.
\end{abstract}

Keywords: web based communities; universities; higher education; social media; Facebook; YouTube; Twitter; MySpace; LinkedIn; Higher Education Institutes; HEIs; virtual communities.

Reference to this paper should be made as follows: Kuzma, J.M. and Wright, W. (2013) 'Using social networks as a catalyst for change in global higher education marketing and recruiting', Int. J. Continuing Engineering Education and Life-Long Learning, Vol. 23, No. 1, pp.53-66.

Biographical notes: Joanne M. Kuzma earned her $\mathrm{PhD}$ in Information Systems at Nova Southeastern University in Fort Lauderdale, Florida and has over 20 years of computer consulting background along with university teaching experience. Currently, she is a Senior Lecturer in Computing for the Worcester Business School at the University of Worcester, Worcester, UK.

Warren Wright has over 20 years experience in higher education and is currently the Associate Head of Worcester Business School at the University of Worcester, UK. He holds a degree in Computing Information Systems and an MBA from Aston University, UK. 


\section{Introduction}

The application of social media for marketing and advertising is now well established in many commercial organisations. Politicians and celebrities are well aware of the promotional benefits of social media can facilitate. Therefore, it is not surprising that HEIs are exploring new opportunities and methods to engage with prospective students, alumni and other stakeholders (Kowalik, 2011). The rapid growth and variety of social media networks suggests that prospective university and college students will be open and positive to institutions adopting these technologies as methods of recruitment (Roach, 2006).

This study explored the extent to which social media technologies are being applied by HEIs for marketing and promotion. There were several objectives to this study:

- determine which prevalent social media sites are most commonly used by top universities in their marketing and recruiting campaigns

- $\quad$ analyse the usage of social media between Asian, European and African universities to determine if there is a difference in usage among the universities in each location.

This paper starts with a review of the current literature surrounding the application of social media by universities and colleges, and a review of related studies. The paper follows with a discussion of the methodology used in this study and then examines the results of the analysis. The paper concludes with a dialogue on implications for global universities on the use of social media for marketing. It reviews the potential cultural change to both the HEIs and potential students required to adopt effective social media adoption.

\section{Literature review}

\subsection{Growth of social media}

There are an increasing number of universities and colleges that are realising the full potential of social media to assist their promotion and marketing. Social network sites can significantly assist with activities such as recruiting students and engaging with alumni. Despite this many HEIs still consider social media as a secondary method of outreach over more traditional approaches. Constantinides and Zinck-Stagno (2011) state that that although future students are interested in social interaction and information seeking when using social media, the context used in most social outreach programmes is limited to video and photo sharing as opposed to social interaction.. The authors indicate that although the penetration of social media is high among students, its impact in their choice of institutions is low compared to traditional forms of university marketing. This is changing as more companies are shifting their marketing budgets from traditional advertising to interactive media. The growth in US social media spending is expected to rise from $\$ 935$ million in 2010 to a projected $\$ 1,860$ million by 2014 (VanBoskirk, 2009).

The number of social media sites has grown tremendously over the past decade and there are a plethora of options that HEIs could adopt for their outreach campaigns. Wikipedia (2012) lists over 200 popular social networking sites, although some of the 
most popular among young university-age students include Facebook, MySpace, Twitter and YouTube. Facebook, a social utility that connects people and friends, has over 500 million worldwide users with the core of the 18 to 24 years old base growing at $74 \%$ per year (DigitalBuzz, 2012). As of April 2012, over three and half thousand universities worldwide have an official presence on Facebook (4ICU, 2012b). People who view a university's page on Facebook can choose to become a 'fan' of the organisation, which shows their personal profile page, as well as allowing them access to information about the university. This can create a viral marketing effect, whereby friends are also likely to become fans of the university (Reuben, 2008).

MySpace is another popular social networking site that allows the customisation of its profile pages. Although, the number of MySpace users has been in a steady decline since 2008, it still has over 60 million monthly visitors worldwide (Arrington, 2011).

Twitter integrated the features of instant messaging and "blogging that allows users to send short (up to 140 character) messages or "tweets" (Reuben, 2008). In 2010, Twitter had approximately 100 million unique users, with $54 \%$ of users falling in the 25 to 44 age group, (Social Media Today, 2011). However, as more users are in the $35+$ age group compared to sites such as Facebook and MySpace, Mansfield (2009) suggests that Twitter may be better suited for recruiting non-traditional or online students instead of targeting those under-17 potential students.

LinkedIn was launched in 2003 and although technically a 'social media site,' its focus is more narrowly defined as a community for business professionals. It has approximately 41 million worldwide participants and is used as a conduit for those interested in establishing professional and business contacts (Socia Media Today, 2011). Although aimed towards the more commercial sector, LinkedIn does have a specific area dedicated to higher education (LinkedIn, 2012). This serves as a potential method of direct communication for those wishing to further their education and seek formal qualifications.

YouTube's main function is video upload, and the site has over 1 billion views daily (Pearson Education, 2010). In 2009, YouTube launched a specific section devoted to academic content, where university professionals can upload educational, marketing and other contents to students and other users (Gilroy, 2009). The site is the most popular social networking site in which schools use as a communication tool with students (Pearson Education, 2010). According to Ratliff (2011), YouTube has the option to create sub-channels that are content specific, as well as creating podcasts of informational materials.

\subsection{Relationship between social networking and HEI education success}

The importance of social media to the recruiting and marketing functions of an HEI can have a direct correlation to the institutions success and influence educational policies. According to Anyangwe (2011), online marketing efforts are tied more closely to a universities success. Richard Taylor of the University of Leicester states that "Marketing considerations are now going to align much more clearly with strategic decision making in universities. Senior management teams in universities will increasingly have to face marketing questions about the brand, the way it is projected and the way they seek to develop it" (Anyangwe, 2011). Thus, a successful electronic marketing and recruiting strategy may have a positive effect of the stakeholders in the education process. 
Wootton (2011) states that online marketing will play an increasing strategic role in reaching prospective students, especially among for-profit institutions. Another area of social media usage that can affect the educational strategy of HEIs is the recruitment of foreign students. As tuition and fees increase in many countries, HEIs are more often relying on recruiting international students to can pay higher fees and thus subsidise part of university financial success. Wheeler (2012) indicates that social media recruiting and marketing is becoming critical to recruiting international students. Accepting more international students can result in more positive educational experiences not only for the international students, but also for domestic students who are exposed to global perspectives. Thus, use of social networking can offer HEIs a more effective method of recruiting international students.

\subsection{Use of social media marketing/recruiting in higher education}

Gilroy (2009) indicates that colleges are boosting their presence on social media sites such as YouTube, and making the most of their potential for marketing as well as a learning tool. She states that higher education has no choice other than to adopt social media. Failure to enlist these technologies will force alumni and/or students to create alternative and unregulated sites and thus the university risks losing complete control of their brand online. Gilroy also suggests HEIs initiate multiple sites to meet different customer demographics, departments, and functions. Mansfield (2009) concurs with the view by also suggesting that HEIs should manage specifically tailored Twitter accounts for different consumer demographics.

Social media can be applied to support a variety of different marketing and promotional activities. Merrill (2011, p.26) states that university admissions and marketing departments could use social networking sites to promote themselves, distribute information, enhance their brand, engage future students, and gain insight into target audience needs and competitor practices. Universities and colleges are using social media to keep students informed of venues and social events. For example, Vanderbilt University in the USA uses social media to promote upcoming concerts at its sports stadium. It found that by using Facebook and Twitter, they could reach students who lived off campus more effectively, increasing the awareness of university events (Tucker, 2011). In 2010, Grenoble Ecole de Management in France wanted create a unique online marketing campaign to boost student recruitment efforts and emphasise the School's strengths and branding. They successfully evoked a three-month marketing campaign on Facebook containing digital applications and videos. The campaign was an overwhelming success with over 2000 potential students accessing the applications (Shinn, 2011).

HEIs have established that social media is an effective conduit to reach students and other stakeholders, particularly when the recipients are already heavily engaged in other social network activities [Merrill, (2011), p.41]. However, as well as being more effective, HEIs are also realising the cost-effectiveness of this approach over more traditional methods such as international travel and print advertising. According to Shinn (2011), smaller schools with limited advertising budgets can use social media to better compete with better-funded institutions. The author quotes an example of William \& Mary's Mason School of Business in Virginia has QR codes on their print literature that leads students to online YouTube promotional videos. Kowalik (2011) gives specific examples of how universities can use Twitter, including a free SMS service to provide 
updates to prospective students during recruitment and using live tweets from alumni during homecoming to provide an authentic tool to look at the day's events and university life. On line marketing through social media offers a cost-effective alternative at a time when many universities cannot rely so heavily on public funding. They are under increasing pressure adopt creative ways to control costs while still maintaining a high level of service (Mandelson, 2009). Although switching to a solely online marketing campaign may not be totally effective, a more diverse set of promotion channels may reduce costs and provide better value for money.

Although the use of social networking has been growing tremendously over the past several years, its use is not without drawbacks. Merrill (2011, p.41) expresses concerns about the ambiguous feedback from social networking marketing and the difficulty in measuring results. Given the relatively recent application of the technology, university staff have little guidance or information on effective online marketing and recruiting strategies. Lewis (2010) states that professionals are enduring a 'trial by fire' method to learn how to use social media effectively as a strategic communication method. The dynamic nature of the technology and sites also makes it difficult to keep abreast of the constant stream of new products, services and innovations. Griffiths and Wall (2011, p.64) state that careful monitoring of social sites is critical, and procedures and standards to manage information on sites should be continuously reviewed and revised.

Lewis (2010) indicates that social media requires a radically different mindset from traditional media planning. As well as understanding the technology, university staff would need to appreciate new marketing approaches and how they differ from traditional printed-based methods. There are also implications for students, despite often being early adopters and heavy users of social media. Students may not necessarily make connections to social media strategically (Lewis, 2010), and will therefore require to acquire and adopt a new skillset to achieve this. As with almost all cultural change education is key to staff and students using social media effectively. University officials will need to play a key role in effecting this change to confirm social media as strategic communication tools.

\subsection{Prior studies}

The have been a number of quantitative studies that have shown the extent to which social media technologies have been adopted. Slover-Linett and Stoner (2010) compiled data from a sample of 1,000 universities worldwide that were members of Council for Advancement and Support of Education (CASE). Their results showed that most institutions used social media, with $94 \%$ using Facebook. $60 \%$ of the institutions also used Twitter, LinkedIn, and/or YouTube. 96\% used social media to communicate with alumni, while only about $57 \%$ used it as a marketing tool for perspective students.

Ganim-Barnes and Mattson (2009) analysed social media adoption among 478 US universities. Their study found that most admissions offices used Facebook for their recruiting campaigns, and 55\% of them were familiar with Twitter. A 2010 study of 30 international university admissions staff found that there was a preference by institutes to use Facebook (96\%) and Twitter (66\%) as their outreach tools. 46\% used YouTube and $33 \%$ used LinkedIn. Respondents to their survey also indicated that social media can be a cost-effective recruiting strategy (Merrill, 2011). 
The results of the above studies provide a useful overview of social media adoption, but as most of the studies were conducted on US institutions, they lack a global perspective. The Slover study presented findings from 1,000 global institutions, but the results were aggregated. Therefore, without further analysis it is difficult to review the preferences of specific geographic regions or countries. This study contributes to the research literature by analysing the application of social media among universities by different geographical regions (Africa, Asia and Europe) and by focusing on non-American universities.

\section{Methodology}

The aim of this study is review the use of social media to support the marketing function in HEIs across three geographical regions (Africa, Asia and Europe) Criteria were applied to choose 90 university sites in nine different countries and to determine which social network sites would form the basis of comparison.

\subsection{Selecting the university sites}

To ensure an equal set of the results the 90 universities were divided evenly across the three geographical areas. From each of area, ten universities from three countries were selected. Each university selected complied with the following criteria.

Firstly, the country and university chosen had to have English as either the primary language or one of the dominant languages of instruction. This use of English also had to be reflected in the university's official website. Secondly, only countries with sizable populations to support a significant number of HEIs were chosen. This was determined by establishing which countries had a minimum of ten universities with websites. The countries chosen within each geographical region were as follows:

- Africa

- Kenya

- South Africa

- Nigeria

- Asia

- India

- Philippines

- Indonesia

- Europe

- UK

- Ireland

- Austria. 
To select the ten universities for each country the online international higher education directory provided by '4 International Colleges \& Universities' (http://www.4icu.org) was consulted. 4icu.org reviews accredited universities in over 200 countries and ranks the university websites based on popularity rankings of search engines (4ICUa, 2012). The ten most popular university websites for each of the nine countries were selected. In one case, one of the top 10 universities for Nigeria had an inactive website and therefore substituted by the next university on the list.

\subsection{Selecting the social media websites}

Given the number of social media websites used globally, it is important to limit and establish a common set of sites for review. The website eBizMBA (ebizmba.com) ranks the top 15 most popular social networking sites based on average web traffic from Alexa Global Traffic rank and US traffic rank from Compete and Quantcast (eBizMBA, 2012). Using this information the following four most popular social networking sites were selected:

- Facebook

- Twitter

- LinkedIn

- MySpace.

YouTube was also selected, despite not being ranked in the top 10 on the eBizMBA website. It was felt that the use of YouTube videos to support marketing and promotion would also reflect the application of social media by universities.

\subsection{Establishing the use of social media for each university}

In order establish the extent to which each social network site was been used for marketing and promotion, e.g., student/alumni recruitment, the following assessments were made against each universities.

- Facebook: A general search for the terms 'recruiting', 'admissions', and 'alumni' was completed for both the top-level of the site as well as the group areas.

- Twitter: A search was initiated against the name of each university. In the case of Austrian universities where the official name of the institute was often 'Universität', a search for both the German and English spelling was performed.

- LinkedIn: A search for the terms 'recruiting', 'admissions', 'and alumni' was completed in the group's directory.

- MySpace: A search of the university name was performed to establish if an official profile for the school has been created.

- YouTube: Searches against the terms: 'welcome', 'admissions,' 'recruiting,' 'alumni,' and 'about' were used. 


\section{Results}

The results collected from the searches above are shown in three separate tables representing each geographical location, Africa (Table 2), Asia (Table 3) and Europe (Table 4). Each table lists each university against its country of domicile followed by five binary indicators of whether the university uses each of the five social networking sites for the purpose of student and alumni marketing. Column name abbreviations are shown in Table 1:

Table 1 Column abbreviations and description

\begin{tabular}{lc}
\hline Column abbreviation & Description \\
\hline Univ. & Name of the university \\
Country & Country of domicile \\
Face & Facebook use indicator \\
Twit & Twitter use indicator \\
Mysp & MySpace use indicator \\
Link & LinkedIn use indicator \\
YouT & YouTube use indicator \\
\hline
\end{tabular}

Results of the Table 2 shows a prevalence of African universities use Facebook (93\%) and LinkedIn (93\%). A fair percentage use Twitter (46\%) and YouTube (36\%) while none of the sites used MySpace. Like their African counterparts, Asian universities (Table 3) show a propensity to use Facebook (83\%) and LinkedIn (90\%). 60\% use Twitter, 53\% use YouTube and 23\% use MySpace. European universities (Table 4) show that the majority use all the sites except for MySpace (23\%)

It is worth noting that there is some difference in usage among continents as well as country. For example, the high usage of Facebook and LinkedIn is consistent among three continents and individual countries. Two interesting results are the use of MySpace and YouTube among geographic regions. No African universities use MySpace while just under a quarter of institutes use it in Asia and Europe. There is also a wide range of participation for YouTube. Only 36\% of African universities use it for their marketing and recruiting, as opposed to $53 \%$ in of Asia and $73 \%$ in Europe.

Table 2 African results

\begin{tabular}{lcccccc}
\hline Univ. & Country & Face & Twit & Mysp & Link & YouT \\
\hline U. Nairobi & Kenya & $\mathrm{Y}$ & $\mathrm{Y}$ & $\mathrm{N}$ & $\mathrm{Y}$ & $\mathrm{N}$ \\
Jomo Kenyatta U. & Kenya & $\mathrm{Y}$ & $\mathrm{N}$ & $\mathrm{N}$ & $\mathrm{Y}$ & $\mathrm{N}$ \\
Kenyatta U. & Kenya & $\mathrm{Y}$ & $\mathrm{Y}$ & $\mathrm{N}$ & $\mathrm{Y}$ & $\mathrm{N}$ \\
Strathmore U. & Kenya & $\mathrm{Y}$ & $\mathrm{N}$ & $\mathrm{N}$ & $\mathrm{Y}$ & $\mathrm{Y}$ \\
Moi U. & Kenya & $\mathrm{Y}$ & $\mathrm{N}$ & $\mathrm{N}$ & $\mathrm{Y}$ & $\mathrm{N}$ \\
US Intern. U. & Kenya & $\mathrm{Y}$ & $\mathrm{N}$ & $\mathrm{N}$ & $\mathrm{Y}$ & $\mathrm{N}$ \\
Daystar U. & Kenya & $\mathrm{Y}$ & $\mathrm{Y}$ & $\mathrm{N}$ & $\mathrm{Y}$ & $\mathrm{Y}$ \\
KCA U. & Kenya & $\mathrm{Y}$ & $\mathrm{Y}$ & $\mathrm{N}$ & $\mathrm{Y}$ & $\mathrm{N}$ \\
Kenya Methodist U. & Kenya & $\mathrm{Y}$ & $\mathrm{N}$ & $\mathrm{N}$ & $\mathrm{Y}$ & $\mathrm{Y}$ \\
\hline
\end{tabular}


Table 2 African results (continued)

\begin{tabular}{|c|c|c|c|c|c|c|}
\hline Univ. & Country & Face & Twit & Mysp & Link & YouT \\
\hline Catholic U. Eastern Africa & Kenya & $\mathrm{Y}$ & $\mathrm{N}$ & $\mathrm{N}$ & $\mathrm{N}$ & $\mathrm{N}$ \\
\hline U. Cape Town & SA & $\mathrm{Y}$ & $\mathrm{N}$ & $\mathrm{N}$ & $\mathrm{Y}$ & Y \\
\hline U. Pretoria & SA & $\mathrm{Y}$ & $\mathrm{Y}$ & $\mathrm{N}$ & Y & Y \\
\hline U. Stellenbosch & SA & $\mathrm{Y}$ & $\mathrm{N}$ & $\mathrm{N}$ & $\mathrm{Y}$ & $\mathrm{Y}$ \\
\hline U. Witwatersrand & SA & Y & $\mathrm{Y}$ & $\mathrm{N}$ & Y & Y \\
\hline U. KwaZulu-Natal & SA & $\mathrm{Y}$ & $\mathrm{N}$ & $\mathrm{N}$ & $\mathrm{Y}$ & $\mathrm{N}$ \\
\hline Rhodes U. & SA & $\mathrm{Y}$ & $\mathrm{Y}$ & $\mathrm{N}$ & $\mathrm{Y}$ & $\mathrm{N}$ \\
\hline U. SA & SA & $\mathrm{Y}$ & $\mathrm{Y}$ & $\mathrm{N}$ & $\mathrm{Y}$ & $\mathrm{N}$ \\
\hline U. Johannesburg & SA & $\mathrm{Y}$ & $\mathrm{N}$ & $\mathrm{N}$ & $\mathrm{Y}$ & $\mathrm{N}$ \\
\hline Cape Peninsula U. & SA & $\mathrm{Y}$ & $\mathrm{Y}$ & $\mathrm{N}$ & $\mathrm{Y}$ & Y \\
\hline Nelson Mandela Met U. & SA & $\mathrm{Y}$ & $\mathrm{Y}$ & $\mathrm{N}$ & $\mathrm{Y}$ & $\mathrm{Y}$ \\
\hline U. Lagos & Nigeria & $\mathrm{Y}$ & $\mathrm{Y}$ & $\mathrm{N}$ & $\mathrm{Y}$ & $\mathrm{N}$ \\
\hline U. Ilorin & Nigeria & $\mathrm{N}$ & $\mathrm{N}$ & $\mathrm{N}$ & $\mathrm{Y}$ & $\mathrm{N}$ \\
\hline U. Ibadan & Nigeria & $\mathrm{Y}$ & $\mathrm{N}$ & $\mathrm{N}$ & $\mathrm{Y}$ & Y \\
\hline U. Benin & Nigeria & $\mathrm{Y}$ & $\mathrm{Y}$ & $\mathrm{N}$ & $\mathrm{Y}$ & $\mathrm{N}$ \\
\hline Lagos State U. & Nigeria & $\mathrm{N}$ & $\mathrm{N}$ & $\mathrm{N}$ & $\mathrm{Y}$ & $\mathrm{N}$ \\
\hline U. Port Harcourt & Nigeria & $\mathrm{Y}$ & $\mathrm{Y}$ & $\mathrm{N}$ & $\mathrm{Y}$ & $\mathrm{N}$ \\
\hline $\begin{array}{l}\text { Federal U. Technology, } \\
\text { Akure }\end{array}$ & Nigeria & $\mathrm{Y}$ & $\mathrm{N}$ & $\mathrm{N}$ & $\mathrm{Y}$ & $\mathrm{N}$ \\
\hline Babcock U. & Nigeria & $\mathrm{Y}$ & $\mathrm{N}$ & $\mathrm{N}$ & $\mathrm{Y}$ & Y \\
\hline University of Uyo & Nigeria & $\mathrm{Y}$ & $\mathrm{Y}$ & $\mathrm{N}$ & $\mathrm{Y}$ & $\mathrm{N}$ \\
\hline Redeemer's University & Nigeria & $\mathrm{Y}$ & $\mathrm{N}$ & $\mathrm{N}$ & $\mathrm{N}$ & $\mathrm{N}$ \\
\hline \multirow[t]{2}{*}{ Total Y's } & & 28 & 14 & 0 & 28 & 11 \\
\hline & & .93 & .46 & 0 & .93 & .36 \\
\hline
\end{tabular}

Table 3 Asian results

\begin{tabular}{lcccccc}
\hline Univ. & Country & Face & Twit & Mysp & Link & YouT \\
\hline Indian Ins. Tech. Bombay & India & $\mathrm{N}$ & $\mathrm{N}$ & $\mathrm{N}$ & $\mathrm{Y}$ & $\mathrm{Y}$ \\
U. Delhi & India & $\mathrm{Y}$ & $\mathrm{Y}$ & $\mathrm{N}$ & $\mathrm{Y}$ & $\mathrm{N}$ \\
Anna U. & India & $\mathrm{Y}$ & $\mathrm{Y}$ & $\mathrm{N}$ & $\mathrm{Y}$ & $\mathrm{N}$ \\
Indian Ins. Tech. Delhi & India & $\mathrm{Y}$ & $\mathrm{N}$ & $\mathrm{N}$ & $\mathrm{Y}$ & $\mathrm{Y}$ \\
Indian Ins. Science & India & $\mathrm{N}$ & $\mathrm{N}$ & $\mathrm{N}$ & $\mathrm{Y}$ & $\mathrm{N}$ \\
Jawaharlal Nehru Tech. U. & India & $\mathrm{Y}$ & $\mathrm{N}$ & $\mathrm{N}$ & $\mathrm{Y}$ & $\mathrm{N}$ \\
Amity U. & India & $\mathrm{Y}$ & $\mathrm{Y}$ & $\mathrm{Y}$ & $\mathrm{Y}$ & $\mathrm{Y}$ \\
U. Mumbai & India & $\mathrm{N}$ & $\mathrm{Y}$ & $\mathrm{N}$ & $\mathrm{Y}$ & $\mathrm{N}$ \\
Birla Ins. Tech. & India & $\mathrm{Y}$ & $\mathrm{N}$ & $\mathrm{N}$ & $\mathrm{Y}$ & $\mathrm{Y}$ \\
U. Pune & India & $\mathrm{Y}$ & $\mathrm{N}$ & $\mathrm{N}$ & $\mathrm{Y}$ & $\mathrm{N}$ \\
U. Philippines Diliman & Philippines & $\mathrm{Y}$ & $\mathrm{Y}$ & $\mathrm{Y}$ & $\mathrm{Y}$ & $\mathrm{Y}$ \\
\hline
\end{tabular}


Table 3 Asian results (continued)

\begin{tabular}{lcccccc}
\hline Univ. & Country & Face & Twit & Mysp & Link & YouT \\
\hline U. Santo Tomas & Philippines & $\mathrm{Y}$ & $\mathrm{Y}$ & $\mathrm{Y}$ & $\mathrm{Y}$ & $\mathrm{Y}$ \\
U. Philippines Los Baños & Philippines & $\mathrm{Y}$ & $\mathrm{Y}$ & $\mathrm{Y}$ & $\mathrm{N}$ & $\mathrm{N}$ \\
U. Philippines Manila & Philippines & $\mathrm{Y}$ & $\mathrm{Y}$ & $\mathrm{N}$ & $\mathrm{Y}$ & $\mathrm{Y}$ \\
U. Philippines Visayas & Philippines & $\mathrm{Y}$ & $\mathrm{Y}$ & $\mathrm{Y}$ & $\mathrm{Y}$ & $\mathrm{Y}$ \\
De La Salle U. & Philippines & $\mathrm{Y}$ & $\mathrm{Y}$ & $\mathrm{Y}$ & $\mathrm{Y}$ & $\mathrm{Y}$ \\
Ateneo de Manila U. & Philippines & $\mathrm{Y}$ & $\mathrm{Y}$ & $\mathrm{N}$ & $\mathrm{Y}$ & $\mathrm{Y}$ \\
MSU-Iligan Ins. Tech. & Philippines & $\mathrm{Y}$ & $\mathrm{N}$ & $\mathrm{N}$ & $\mathrm{Y}$ & $\mathrm{N}$ \\
Mapúa Ins. Tech. & Philippines & $\mathrm{Y}$ & $\mathrm{N}$ & $\mathrm{Y}$ & $\mathrm{N}$ & $\mathrm{Y}$ \\
Far Eastern U. & Philippines & $\mathrm{Y}$ & $\mathrm{Y}$ & $\mathrm{N}$ & $\mathrm{Y}$ & $\mathrm{Y}$ \\
InsTeknologi Bandung & Indonesia & $\mathrm{Y}$ & $\mathrm{Y}$ & $\mathrm{N}$ & $\mathrm{Y}$ & $\mathrm{Y}$ \\
U. Indonesia & Indonesia & $\mathrm{Y}$ & $\mathrm{Y}$ & $\mathrm{N}$ & $\mathrm{Y}$ & $\mathrm{Y}$ \\
U. GadjahMada & Indonesia & $\mathrm{Y}$ & $\mathrm{Y}$ & $\mathrm{N}$ & $\mathrm{Y}$ & $\mathrm{Y}$ \\
In TekSepuluh & Indonesia & $\mathrm{Y}$ & $\mathrm{Y}$ & $\mathrm{N}$ & $\mathrm{Y}$ & $\mathrm{N}$ \\
U. Gunadarma & Indonesia & $\mathrm{Y}$ & $\mathrm{Y}$ & $\mathrm{N}$ & $\mathrm{Y}$ & $\mathrm{N}$ \\
U. Bina Nusantara & Indonesia & $\mathrm{N}$ & $\mathrm{N}$ & $\mathrm{N}$ & $\mathrm{N}$ & $\mathrm{N}$ \\
U. Kristen Petra & Indonesia & $\mathrm{N}$ & $\mathrm{N}$ & $\mathrm{N}$ & $\mathrm{Y}$ & $\mathrm{N}$ \\
U. SebelasMaret & Indonesia & $\mathrm{Y}$ & $\mathrm{N}$ & $\mathrm{N}$ & $\mathrm{Y}$ & $\mathrm{N}$ \\
U. Sumatera Utara & Indonesia & $\mathrm{Y}$ & $\mathrm{N}$ & $\mathrm{N}$ & $\mathrm{Y}$ & $\mathrm{N}$ \\
U. Pendidikan & Indonesia & $\mathrm{Y}$ & $\mathrm{Y}$ & $\mathrm{N}$ & $\mathrm{Y}$ & $\mathrm{Y}$ \\
Total & 25 & 18 & 7 & 27 & 16 \\
& & .83 & .60 & .23 & .90 & .53 \\
\hline
\end{tabular}

Table 4 European results

\begin{tabular}{lcccccc}
\hline Univ. & Country & Face & Twit & Mysp & Link & YouT \\
\hline U. Cambridge & $\mathrm{UK}$ & $\mathrm{Y}$ & $\mathrm{Y}$ & $\mathrm{Y}$ & $\mathrm{Y}$ & $\mathrm{Y}$ \\
U. Oxford & $\mathrm{UK}$ & $\mathrm{Y}$ & $\mathrm{Y}$ & $\mathrm{N}$ & $\mathrm{Y}$ & $\mathrm{Y}$ \\
Imp C London & $\mathrm{UK}$ & $\mathrm{Y}$ & $\mathrm{Y}$ & $\mathrm{Y}$ & $\mathrm{Y}$ & $\mathrm{Y}$ \\
U. C London & $\mathrm{UK}$ & $\mathrm{Y}$ & $\mathrm{Y}$ & $\mathrm{Y}$ & $\mathrm{Y}$ & $\mathrm{Y}$ \\
U. Manchester & $\mathrm{UK}$ & $\mathrm{Y}$ & $\mathrm{Y}$ & $\mathrm{Y}$ & $\mathrm{Y}$ & $\mathrm{Y}$ \\
U. Edinburgh & $\mathrm{UK}$ & $\mathrm{Y}$ & $\mathrm{Y}$ & $\mathrm{Y}$ & $\mathrm{Y}$ & $\mathrm{Y}$ \\
U. Leeds & $\mathrm{UK}$ & $\mathrm{Y}$ & $\mathrm{Y}$ & $\mathrm{Y}$ & $\mathrm{Y}$ & $\mathrm{Y}$ \\
U. Nottingham & $\mathrm{UK}$ & $\mathrm{Y}$ & $\mathrm{Y}$ & $\mathrm{Y}$ & $\mathrm{Y}$ & $\mathrm{Y}$ \\
London Sch Econ & $\mathrm{UK}$ & $\mathrm{Y}$ & $\mathrm{Y}$ & $\mathrm{N}$ & $\mathrm{Y}$ & $\mathrm{Y}$ \\
U. York & $\mathrm{UK}$ & $\mathrm{Y}$ & $\mathrm{Y}$ & $\mathrm{N}$ & $\mathrm{Y}$ & $\mathrm{Y}$ \\
U. College Dublin & Ireland & $\mathrm{Y}$ & $\mathrm{Y}$ & $\mathrm{N}$ & $\mathrm{Y}$ & $\mathrm{Y}$ \\
Trinity C Dublin & Ireland & $\mathrm{Y}$ & $\mathrm{Y}$ & $\mathrm{N}$ & $\mathrm{Y}$ & $\mathrm{Y}$ \\
U. College Cork & Ireland & $\mathrm{Y}$ & $\mathrm{Y}$ & $\mathrm{N}$ & $\mathrm{Y}$ & $\mathrm{Y}$ \\
\hline
\end{tabular}


Table 4 European results (continued)

\begin{tabular}{|c|c|c|c|c|c|c|}
\hline Univ. & Country & Face & Twit & Mysp & Link & YouT \\
\hline Dublin City U. & Ireland & $\mathrm{Y}$ & $\mathrm{Y}$ & $\mathrm{N}$ & $\mathrm{Y}$ & $\mathrm{Y}$ \\
\hline Nat. U. Ireland, Galway & Ireland & Y & Y & $\mathrm{N}$ & $\mathrm{Y}$ & $\mathrm{Y}$ \\
\hline U. Limerick & Ireland & $\mathrm{Y}$ & Y & $\mathrm{N}$ & $\mathrm{Y}$ & $\mathrm{Y}$ \\
\hline Dublin Ins Tech & Ireland & Y & Y & $\mathrm{N}$ & $\mathrm{Y}$ & $\mathrm{Y}$ \\
\hline Nat. U. Ireland, Maynooth & Ireland & $\mathrm{N}$ & $\mathrm{Y}$ & $\mathrm{N}$ & $\mathrm{N}$ & $\mathrm{N}$ \\
\hline Royal C of Surgeons & Ireland & $\mathrm{N}$ & $\mathrm{N}$ & $\mathrm{N}$ & $\mathrm{Y}$ & $\mathrm{N}$ \\
\hline Waterford Ins. Tech. & Ireland & $\mathrm{Y}$ & $\mathrm{Y}$ & $\mathrm{N}$ & $\mathrm{Y}$ & $\mathrm{Y}$ \\
\hline UWien & Austria & $\mathrm{Y}$ & $\mathrm{N}$ & $\mathrm{N}$ & $\mathrm{Y}$ & $\mathrm{Y}$ \\
\hline Tech. U. Wien & Austria & $\mathrm{Y}$ & $\mathrm{Y}$ & $\mathrm{N}$ & $\mathrm{Y}$ & $\mathrm{Y}$ \\
\hline U. Innsbruck & Austria & $\mathrm{Y}$ & $\mathrm{Y}$ & $\mathrm{N}$ & $\mathrm{Y}$ & $\mathrm{N}$ \\
\hline U. Graz & Austria & $\mathrm{Y}$ & $\mathrm{Y}$ & $\mathrm{N}$ & $\mathrm{Y}$ & $\mathrm{Y}$ \\
\hline U. Linz & Austria & $\mathrm{N}$ & $\mathrm{N}$ & $\mathrm{N}$ & $\mathrm{N}$ & $\mathrm{N}$ \\
\hline U Bodenkultur Wien & Austria & $\mathrm{N}$ & $\mathrm{N}$ & $\mathrm{N}$ & $\mathrm{N}$ & $\mathrm{Y}$ \\
\hline Alpen-Adria-U. & Austria & $\mathrm{Y}$ & $\mathrm{N}$ & $\mathrm{N}$ & $\mathrm{Y}$ & $\mathrm{N}$ \\
\hline U. Salzburg & Austria & $\mathrm{N}$ & $\mathrm{Y}$ & $\mathrm{N}$ & $\mathrm{Y}$ & $\mathrm{N}$ \\
\hline Medizinische U. Wien & Austria & $\mathrm{N}$ & $\mathrm{N}$ & $\mathrm{N}$ & $\mathrm{Y}$ & $\mathrm{N}$ \\
\hline U. MusikKunst Graz & Austria & $\mathrm{N}$ & $\mathrm{N}$ & $\mathrm{N}$ & $\mathrm{N}$ & $\mathrm{N}$ \\
\hline \multirow[t]{2}{*}{ Total } & & 23 & 23 & 7 & 26 & 22 \\
\hline & & .77 & .76 & .23 & .87 & .73 \\
\hline
\end{tabular}

\section{Implications, discussion and future studies}

The results indicate that that the level of usage among social media is variable and dependent on geographical regions for some social media sites. The use of the ubiquitous Facebook and LinkedIn are high among all geographic locations, while Twitter, MySpace and YouTube show uneven levels of usage. The findings would suggest that some universities are not taking full advantage of the global reach that these social media sites have with potential students, thus ignoring a prime marketing channel.

A global survey from PEW internet (Finn, 2011) shows a marked difference in social networking usage among countries. For example, in the USA, 50\% of the survey respondents used social networking sites, $43 \%$ in the UK, while countries Africa had much lower usage. This research supports the findings of this study, which show that overall; universities in Africa did tend to have lower rates of social network participation than their European and Asian counterparts.

One explanation for these results may lie in the cultural difference in attitudes and social media usage between the university officials who create the marketing and recruiting campaigns and their audience. Mutai (2012) states that African Twitter users aged 20 to 29 are active across the range of social media sites, including Facebook, YouTube and LinkedIn. However, the author cautions that public and business figures have not joined the social media revolution to the same extent as the younger generation. 
Mangold and Faulds (2009) state that because social media is a hybrid of the promotion mix, marketing officials must learn to adapt social media to shape consumer conversations in a manner consistent with the firm's mission and performance goals. This includes providing consumers with a variety of communication methods to engage potential students e.g., 'blogs, and media and promotion tools.

Although the use of social media is growing and both students and university officials are keen to embrace this technology, it should be noted that its application should be only one aspect of a HEIs recruiting and marketing strategy. Roach (2006) indicates that in a study of 1,000 potential university students, only $56 \%$ indicated that they preferred web sources to print materials in outreach. Therefore, universities need a diverse range of outreach materials to meet a changing audience and should not invest all their resources in adopting social media. However, as this study has shown, the use of social media can provide new cost effective marketing and promotion channels to reach of a young audience.

Further research is necessary to understand the global prevalence of social media in HEI. For example, studying a greater number of universities in each country may show different results in social media marketing outreach. Another area for exploration could be an analysis of social networking sites that are more culturally focused to users in specific geographical regions or languages. It should not be assumed that the five social sites tested in this study are the best marketing and recruiting channels for all countries and universities. For example, China regularly blocks a host of internet services, including Twitter, live.com, and YouTube (Jacobs, 2009). Regular blocking of some social networking sites may not leave their functions conducive to marketing campaigns if a business or entity cannot count on their campaign actually reaching their intended audience. Fu (2009) indicates that Facebook is only ranked number 11 in social network users in China, in a market dominated by local sites. Further research could reveal that universities are using dominant local social network sites as well as global ones.

\section{Conclusions}

The purpose of this study was to explore global reach of social networking site usage among universities in Africa, Asia and Europe. Primary research was conducted using web searches of five common social networking sites among 90 universities in Asia, Africa and Europe. The study contributes to existing literature and supports the prior studies by Slover-Linett and Stoner (2010) and Merrill (2011) demonstrating the widespread use of Facebook. The results of these studies complemented our results showing a range of $77 \%$ to $94 \%$ of institutes using Facebook for university marketing and recruiting. This study goes further in categorising universities into three geographical areas, and determining that for some social networking sites, there is a variable in levels of usage.

\section{References}

4ICU (2012a) 4ICU About US [online] http://www.4icu.org/menu/about.htm (accessed 25 February 2012).

4ICU (2012b) Colleges and Universities on Facebook [online] http://www.4icu.org/facebook/ (accessed 1 April 2012). 
Anyangwe, E. (2011) 'How to market higher education during times of change', [online] http://www.guardian.co.uk/higher-education-network/blog/2011/apr/06/ higher-education-reputation-management-marketing (accessed 3 August 2012).

Arrington, M. (2011) MySpace Stabilizes Unique Visitors, But All Other Usage Stats Plummet [online] http://techcrunch.com/2011/05/11/ myspace-stabilizes-unique-visitors-but-all-other-usage-stats-plummet/ (accessed 1 April 2012).

Constantinides, E. and Zinck-Stagno, M. (2011) 'Potential of the social media as instruments of higher education marketing: a segmentation study', Journal of Marketing for Higher Education, Vol. 21, No. 1, pp.7-24.

DigitalBuzz (2012) Facebook Statistics, Stats \& Facts for 2011 [online] http://www.digitalbuzzblog.com/facebook-statistics-stats-facts-2011/ (accessed 1 April 2012).

eBizMBA (2012) Top 15 Most Popular Social Networking Sites, January [online] http://www.ebizmba.com/articles/social-networking-websites (accessed 24 February 2012).

Finn, G. (2011) Global Report: US 2nd in Social Networking \& 3rd in Mobile Internet Usage, [online] http://marketingland.com/ global-report-u-s-2nd-in-social-networking-3rd-in-mobile-internet-usage-1834 (accessed 21 March 2012).

Fu, R. (2009) Chinese Social Networking Sites Dominated by Local Players [online] http://www.chinainternetwatch.com/103/chinese-sns-dominated-by-local-players/ (accessed 10 March 2012).

Ganim-Barnes, N. and Mattson, E. (2009) Social Media and College Admissions: Higher-Ed Beats Business in Adoption of New Tools for Third Year, University of Massachusetts Center for Marketing Research [online] http://www.umassd.edu/media/umassdartmouth/cmr/studiesandresearch/ socialmediaadmissions.pdf (accessed 5 March 2012).

Gilroy, M. (2009) 'Higher education migrates to YouTube and social networks', The Hispanic Outlook in Higher Education, Vol. 19, pp.12-14.

Griffiths, P. and Wall, A. (2011) 'Social media use by enrollment management', in Wankel, L. and Wankel, C. (Eds.): Higher Education Administration with Social Media, pp.49-70, Emerald Group Publishing.

Jacobs, A. (2009) 'China requires censorship software on new PCs', The New York Times [online] http://www.legaboom.com/ support-files/chinarequirescensorshipsoftwareoncomputerjune09.pdf (accessed 15 March 2012).

Kowalik, E. (2011) 'Engaging alumni and prospective students through social media', in Wankel, L. and Wankel, C. (Eds.): Higher Education Administration with Social Media, pp.211-227, Emerald Group Publishing.

Lewis, B. (2010) 'Social media and strategic communication: attitudes and perceptions among college students', Public Relations Journal, Vol. 4, No. 3 [online] $\mathrm{http}: / /$ www.prsa.org/Intelligence/PRJournal/Documents/social_media_and_strategic_communi cation.pdf (accessed 13 March 2012).

LinkedIn (2012) Higher Education Today [online] http://www.linkedin.com/today/higher_education (accessed 28 February 2012).

Mandelson, P. (2009) 'Higher ambitions - the future of universities in a knowledge economy' [online] http://www.bis.gov.uk/assets/biscore/corporate/docs/h/ 09-1452-higher-ambitions-summary (accessed 29 February 2012).

Mangold, W. and Faulds, D. (2009) 'Social media: the new hybrid element of the promotion mix', Business Horizons, Vol. 52, No. 4, pp.357-365.

Mansfield, H. (2009) '10 Twitter tips for higher education', University Business Magazine [online] http://www.universitybusiness.com/article/10-twitter-tips-higher-education (accessed 24 February 2012). 
Merrill, N. (2011) 'Social media for social research: applications for higher education communications', in Wankel, L. and Wankel, C. (Eds.): Higher Education Administration with Social Media, pp.25-48, Emerald Group Publishing.

Mutai, P. (2012) 'Young people drive growth of Twitter in Africa via mobile devices: study' [online] http://news.xinhuanet.com/english/sci/2012-01/26/c 131377908.htm (accessed 16 March 2012).

Pearson Education (2010) First-of-Its-Kind Survey Finds College Faculty Increasingly Using Social Media [online] http://www.pearsoned.com/sociable-professors/ (accessed 1 April 2012).

Ratliff, A. (2011) 'Are they listening? Social media on campuses of higher education', The Journal of Technology in Student Affairs, Summer [online] http://studentaffairs.com/ejournal/Summer_2011/AreTheyListening.html (accessed 1 April 2012).

Reuben, R. (2008) 'The use of social media in higher education for marketing and communications: a guide for professionals in higher education' [online] http://doteduguru.com/ wp-content/uploads/2008/08/social-media-in-higher-education.pdf (accessed 13 March 2012).

Roach, R. (2006) 'Prospective college students receptive to electronic social networking recruitment methods, survey finds', Diverse Issues in Higher Education, Vol. 23, No. 23, p.40.

Shinn, S. (2011) 'Marketing 2.0', BizEd, Vol. 10, No. 2, pp.32-36.

Slover-Linett, C. and Stoner, M. (2010) 'Succeeding with social media: lessons from the first survey of social media', Slover Linett Issue Paper Series [online] http://www.sloverlinett.com/files/mStoner-SloverLinett\%20White\%20Paper.pdf (accessed 10 March 2012).

Social Media Today (2011) Who Uses Facebook, Twitter, LinkedIn, \& MySpace? 4thQ \& 1stQ Stats and Analysis [online] http://socialmediatoday.com/paulkiser/285851/ who-uses-facebook-twitter-linkedin-myspace-4thq-1stq-stats-and-analysis (accessed 1 April 2012).

Tucker, K. (2011) 'College credit', Billboard, Vol. 123, No. 36, p.28.

VanBoskirk, S. (2009) 'US interactive marketing forecast, 2009 to 2014', Forrester Research [online] http://www.forrester.com/go?docid=47730 (accessed 1 April 2012).

Wheeler, D. (2012) 'New twists in online recruiting of international students' [online] http://chronicle.com/blogs/planet/2012/04/08/ new-twists-in-online-recruiting-of-international-students/ (accessed 3 August 2012).

Wikipedia (2012) List of Social Networking Websites [online] http://en.wikipedia.org/wiki/List_of_social_networking_websites (accessed 1 April 2012).

Wootton, R. (2011) 'Survey shows educational institutions increasingly going online to reach and attract students' [online] http:/www.universitybusiness.com/news/ survey-shows-educational-institutions-increasingly-going-online-reach-and-attract-students (accessed 3 August 2012). 